\title{
Greenhouse Gas Emissions from Cattle Production Sector in South Korea
}

\author{
Febrisiantosa $\mathrm{A}^{1,2}$, Lee $\mathrm{JH}^{1}$, Choi $\mathrm{HL}^{1,2}$ \\ ${ }^{1}$ Department of Agricultural Biotechnology and Research Institute for Agricultural and Life \\ Science, Seoul National University, Seoul, Republic of Korea, 151-742. \\ ${ }^{2}$ Research Unit for Natural Product Technology, Indonesian Institute of Sciences, \\ Jl. Jogja Wonosari km 32, Gading Playen, Gunungkidul, Yogyakarta, Indonesia \\ ${ }^{2}$ Resourcification Research Center for Crop-Animal Farming (ReCAF), Gwanak-gu, Seoul. S. Korea \\ E-mail: andi82@snu.ac.kr
}

(received 22-04-2016; revised 10-05-2016; accepted 29-06-2016)

\begin{abstract}
ABSTRAK
Febrisiantosa A, Lee JH, Choi HL. 2016. Emisi gas rumah kaca dari sektor produksi ternak di Korea Selatan. JITV 21(2): 112123. DOI: http://dx.doi.org/10.14334/jitv.v21i2.1359

Negara Korea Selatan menyatakan akan mengurangi emisi gas rumah kaca sebanyak 30\% dari level emisi saat ini pada tahun 2020. Penelitian ini dilakukan untuk mengevaluasi emisi gas rumah kaca dari sektor produksi sapi potong di Korea Selatan. Emisi gas rumah kaca dari aktivitas produksi sapi perah, sapi lokal Non-Korea dan sapi lokal Korea (Hanwoo) di 16 provinsi Korea Selatan selama sepuluh tahun (2005-2014) diestimasikan menggunakan metode khusus berdasarkan Guidelines for National Greenhouse Gas Inventory of the IPCC (2006). Emisi yang dievaluasi dalam penelitian ini meliputi gas metan dari fermentasi enterik, gas metan dari pengelolaan kotoran, oksida nitrat dari pengelolaan kotoran dan karbon dioksida dari penggunaan energi secara langsung. Lebih dari 10 tahun terakhir, aktivitas produksi sapi Hanwoo merupakan penyumbang utama (83.52\% dari total emisi sektor produksi ternak sapi) $\mathrm{CH}_{4}$ dari fermentasi enteric, $\mathrm{CH}_{4}$ dari pengelolaan kotoran, $\mathrm{NO}_{2}$ dari pengelolaan kotoran dan $\mathrm{NO}_{2}$ dari penggunaan energi secara langsung pada sektor peternakan sapi di Korea Selatan.
\end{abstract}

Kata Kunci: Metan, Oksida Nitrat, Karbondioksida, Sapi, Pemanasan Global

\begin{abstract}
Febrisiantosa A, Lee JH, Choi HL. 2016. Greenhouse gas emissions from cattle production sector in South Korea. JITV 21(2): 112-123. DOI: http://dx.doi.org/10.14334/jitv.v21i2.1359

South Korea has declared to reduce greenhouse gas emissions by $30 \%$ compared to the current level by the year 2020 . The greenhouse gas emissions from the cattle production sector in South Korea were evaluated in this study. The greenhouse gas emissions of dairy cattle, Non-Korean native cattle and Korean native (Hanwoo) cattle production activities in 16 local administrative provinces of South Korea over a ten-year period (2005-2014) were estimated using the methodology specified by the Guidelines for National Greenhouse Gas Inventory of the IPCC (2006). The emissions studied herein included methane from enteric fermentation, methane from manure management, nitrous oxide from manure management and carbon dioxide from direct on-farm energy use. Over the last ten years, Hanwoo cattle production activities were the primary contributor of $\mathrm{CH}_{4}$ from enteric fermentation, $\mathrm{CH}_{4}$ from manure management, $\mathrm{NO}_{2}$ from manure management and $\mathrm{CO}_{2}$ from on-farm energy use in the cattle livestock sector of South Korea, which comprised to $83.52 \%$ of total emissions from cattle production sector.
\end{abstract}

Key Words: Methane, Nitrous Oxide, Carbon Dioxide, Cattle, Global Warming

\section{INTRODUCTION}

Greenhouse gas (GHG) emissions from human activities become a focus of worldwide attention because of global warming issues. With global warming, the equilibrium of ecosystems is threatened by climate change. The agricultural sector contributes $18 \%$ (7.1 billion tonnes $\mathrm{CO}_{2}$ equivalent) to the total global greenhouse gas emissions (FAO 2006). Although agricultural activity contributes only $9 \%$ to global $\mathrm{CO}_{2}$ emissions, agriculture generates $65 \%$ of human-related nitrous oxide $\left(\mathrm{N}_{2} \mathrm{O}\right)$ and $35 \%$ of methane $\left(\mathrm{CH}_{4}\right)$ with global warming potentials (GWPs) of 298-fold and 25- fold that of $\mathrm{CO}_{2}$, respectively (USEPA 2014; IPCC 2006; Smith et al. 2007). South Korea pledged to reduce greenhouse gas emissions by $30 \%$ below the current levels by 2020 or by $4 \%$ below the levels of 2005 (UNFCCC 2011; Gerber et al. 2013). Livestock production is a critical contributor in agricultural activity that produces greenhouse gases and contributes approximately $42 \%$ to the total GHG emissions, with $28 \%$ of the emissions directly from enteric fermentation and $14 \%$ from indirect emissions due to the handling, storage, and land application of manure (AAFCCT 2000). 
Production of cattle is an important part of economic growth of the livestock industry as it meets the increasing demand of meat and milk products. However, along the production, greenhouse gases are emitted. Few studies have estimated GHG emissions from livestock sector that follow the IPCC guidelines. Merino et al. (2011) inventoried the regional methane and nitrous oxide emissions from ruminant livestock in Basque country, and Patra (2014) studied the trends and projected estimation of GHG emissions from Indian livestock in comparison with the global GHG emissions and those from developing countries. In South Korea, Ji \& Park (2012) found that the annual growth rates of enteric $\mathrm{CH}_{4}$ emissions and $\mathrm{CH}_{4}$ and $\mathrm{N}_{2} \mathrm{O}$ emissions from manure management from 1990 to 2009 were $1.7 \%, 2.6 \%$ and $3.2 \%$, respectively. Lee \& Lee (2003) investigated national methane emissions from the enteric fermentation of livestock, and Jo et al. (2015) estimated methane emissions factor from enteric fermentation of Hanwoo steers. Amon et al. (2006) estimated GHG emissions from different management system of dairy cattle. In South Korea, Korean native (Hanwoo) cattle population is already be distinguished from the other beef producing cattle breed population. Other source of beef production is the dairy cattle steers which is categorized as Non-Korean native cattle. However, the information has not been obtained for recent GHG emissions from cattle production activities in South Korea. Therefore, the aim of this study was to estimate the emissions of greenhouse gases from the cattle production sector, including estimates for on-farm energy use, in South Korea.

\section{MATERIALS AND METHODS}

\section{Scope and activity data}

This study focused on three primary emission sources in cattle production activities: Emissions from enteric fermentation, emissions from manure management, and emissions from direct on-farm energy use. Methane was emitted from enteric fermentation and manure management, nitrous oxide from manure management and carbon dioxide from on-farm energy use. Data of livestock populations in South Korea were adopted from the Korean Statistical Information Services. Populations of cattle were based on the average of each annual quartile. Cattle population data between 2005 and 2014 are shown in Table 1. The cattle were divided into three categories (breed, age and sex). The breed category was divided into three subcategories (Hanwoo, beef, and dairy cattle), the age category was divided into three subcategories (under 1 $y, 1-2 y$, and over $2 \mathrm{y}$ ), and the sex was divided into two subcategories (male and female), except for the dairy cattle. The population estimates are presented for 16 local administrative provinces in South Korea.

\section{Estimation of greenhouse gas emissions}

Current assessment used a methodology specified in the Guidelines for National Greenhouse Gas Inventory (IPCC 2006) and the Greenhouse gas emissions from ruminant supply chains (Opio et al. 2013). The emissions were assessed in 16 local administrative provinces of South Korea. Global Warming Potentials (GWPs), based on the 4th Assessment Report of the IPCC (IPCC 2006), were used to convert $\mathrm{N}_{2} \mathrm{O}$ and $\mathrm{CH}_{4}$ values to $\mathrm{CO}_{2}$-eq values. Consequently, the GWPs of 25 and 298 were used for $\mathrm{CH}_{4}$ and $\mathrm{N}_{2} \mathrm{O}$, respectively.

Approaches used to estimate the emissions from cattle production were Tier- 1 and Tier- 2 methods in the IPCC guidelines. In this study, the different value of enteric fermentation factor was used for Hanwoo and Non-Korean native cattle since Korea has different category of beef production cattle. Default emission factors for the Tier-1 method were provided by the IPCC (2006). For some approaches using Tier-2

Table 1. Cattle population in South Korea (2005-2014)

\begin{tabular}{lccc}
\hline \hline Year & Korean native (Hanwoo) cattle (heads) & Non-Korean native cattle (heads) & Dairy cattle (heads) \\
\hline 2005 & $1,582,446$ & 181,301 & 487,882 \\
2006 & $1,781,256$ & 177,743 & 471,214 \\
2007 & $1,990,379$ & 170,248 & 456,387 \\
2008 & $2,232,247$ & 165,220 & 446,319 \\
2009 & $2,432,454$ & 154,976 & 442,373 \\
2010 & $2,709,201$ & 157,362 & 435,048 \\
2011 & $2,839,829$ & 142,216 & 401,628 \\
2012 & $2,937,828$ & 124,854 & 412,828 \\
2013 & $2,884,541$ & 113,318 & 421,135 \\
2014 & $2,724,879$ & 92,275 & 427,782 \\
\hline
\end{tabular}


Table 2. Approaches to estimate GHG emissions from cattle production in South Korea (2005-2014)

\begin{tabular}{lccc}
\hline \hline Emission sector & $\begin{array}{c}\text { Korean native } \\
\text { (Hanwoo) cattle }\end{array}$ & $\begin{array}{c}\text { Non-Korean native } \\
\text { cattle }\end{array}$ & $\begin{array}{c}\text { Dairy } \\
\text { cattle }\end{array}$ \\
\hline $\mathrm{CH}_{4}$ emissions from enteric fermentation & Tier-2 & Tier-2 & Tier-2 \\
$\mathrm{CH}_{4}$ emissions from manure management & Tier-2 & Tier-2 & Tier-1 \\
$\mathrm{N}_{2} \mathrm{O}$ emissions from manure management & Tier-1 & Tier-1 & Tier-1 \\
$\mathrm{CO}_{2}$ emissions from direct on-farm energy use for livestock & Tier-1 & Tier-1 & Tier-1 \\
\hline
\end{tabular}

method, country-specific information was required. The estimations of emission factors for the Tier-2 method were adopted from the IPCC guidelines. Characteristics of the approaches used to estimate GHG emissions for cattle production are shown in Table 2. The estimation was conducted in 3 steps. In step 1, cattle population was classified into subgroups and each subgroup was characterized. In step 2, emission factor was estimated for each subgroup in kilograms of gas emission per animal per year.

In step 3, to estimate the emissions for the different subgroups, the emission factors of each subgroup were multiplied by the population size of that subgroup; the emissions of the subgroups were then summed to estimate total emission.

\section{RESULTS AND DISCUSSION}

\section{$\mathrm{CH}_{4}$ emission from enteric fermentation}

Cattle consume organic matter that is degraded by rumen microbes with the production of $\mathrm{CH}_{4}$ as a final product of metabolism; thus, enteric fermentation in cattle is a source of $\mathrm{CH}_{4}$ emission. Tier- 2 method was used in this estimation. Tier-2 methodology is more appropriate than the Tier-1 (Höglund-Isaksson 2012).
Emission factors for methane enteric fermentation from cattle in South Korea are provided in Table 3, which was used to estimate enteric methane emission.

$\mathrm{CH}_{4}$ emissions from cattle enteric fermentation of South Korea are shown in Table 4. Annual $\mathrm{CH}_{4}$ emissions from the enteric fermentation of dairy cattle in the 16 provinces of South Korea between 2005 and 2014 decreased about $17.41 \%$. However, it starts to increase after 2011. The highest $\mathrm{CH}_{4}$ emissions from dairy cattle enteric fermentation was recorded in Gyeonggi. In seven of the provinces, the $\mathrm{CH}_{4}$ emissions from dairy cattle enteric fermentation decreased in 2011 but then increased in 2014, compared to the emission in 2011. The local administrative provinces with decreased emission from dairy cattle enteric fermentation in 2014 compared to that in 2005 was Daegu (-56\%), Daejeon (-100\%) and Jeju (-18\%).

The local administrative province with increased $\mathrm{CH}_{4}$ emissions from dairy cattle enteric fermentation in 2014 compared to that in 2005 was Chungcheongnam $(+8 \%)$. From enteric fermentation, dairy cattle emitted $1.19 \mathrm{Mt} \mathrm{CO}_{2}$-eq in 2001 (Lee \& Lee 2003), whereas in this study, dairy cattle emitted $1.21 \mathrm{Mt} \mathrm{CO}_{2}$-eq in 2014. The total methane emissions from enteric fermentation did not increase significantly because the population remained constant during the last ten years.

Table 3. Emission factors to estimate methane emissions from enteric fermentation of cattle in South Korea

\begin{tabular}{lccc}
\hline \hline Cattle & \multicolumn{3}{c}{ Emission factor (kg CH$/$ head/year) } \\
\hline Korean native (Hanwoo) & under 1 year & $1 \sim 2$ years & 2 years and over \\
Male & 36.2 & 71.5 & 76.1 \\
Female & 34.3 & 63.6 & 73.1 \\
Non-Korean native & under 1 year & $1 \sim 2$ years & 2 years and over \\
Male & 51.5 & 69.1 & 98.3 \\
Female & 23.0 & 50.7 & 63.5 \\
Dairy & under 1 year & $1 \sim 2$ years & 2 years and over \\
& 41.24 & 53.55 & 53.40 \\
\hline
\end{tabular}


Table 4. $\mathrm{CH}_{4}$ emissions from the enteric fermentation of cattle in South Korea (2005-2014)

\begin{tabular}{lcccc}
\hline \hline Year & $\begin{array}{c}\text { Korean native (Hanwoo) cattle } \\
\left(\text { Mt CO}_{2} \text {-eq/year) }\right.\end{array}$ & $\begin{array}{c}\text { Non-Korean native cattle } \\
\left(\mathrm{Mt} \mathrm{CO}_{2} \text {-eq/year }\right)\end{array}$ & $\begin{array}{c}\text { Dairy cattle } \\
\left(\mathrm{Mt} \mathrm{CO}_{2} \text {-eq/year }\right)\end{array}$ & $\begin{array}{c}\text { Total } \\
\left(\mathrm{Mt} \mathrm{CO}_{2} \text {-eq/year }\right)\end{array}$ \\
\hline 2005 & 2.33 & 0.26 & 1.33 & 3.91 \\
2006 & 2.64 & 0.25 & 1.27 & 4.17 \\
2007 & 2.96 & 0.25 & 1.24 & 4.44 \\
2008 & 3.35 & 0.24 & 1.20 & 4.79 \\
2009 & 3.67 & 0.23 & 1.19 & 5.09 \\
2010 & 4.10 & 0.23 & 1.18 & 5.51 \\
2011 & 4.31 & 0.22 & 1.09 & 5.62 \\
2012 & 4.47 & 0.19 & 1.16 & 5.82 \\
2013 & 4.44 & 0.18 & 1.19 & 5.80 \\
2014 & 4.21 & 0.14 & 1.21 & 5.57 \\
\hline
\end{tabular}

Between 2005 and 2014, $\mathrm{CH}_{4}$ emissions from the enteric fermentation of Non-Korean native cattle in South Korea decreased only about $0.46 \%$ or about 0.12 Mt CO2-eq. In all 16 provinces except for Busan, less $\mathrm{CH}_{4}$ was emitted from Non-Korean native cattle enteric fermentation in 2005 compared to that in 2014. The largest $\mathrm{CH}_{4}$ emissions decreasing between 2005 to 2014 was from Non-Korean native cattle in Chungcheongbuk with a decrease of $0.019 \mathrm{CO} 2$-eq or about $52 \%$ compare to the initial. Local province with an increase of $\mathrm{CH}_{4}$ emissions from Non-Korean native cattle enteric fermentation was Busan that increased the emission by about $10 \%$ during the last ten years. From the enteric fermentation of Hanwoo cattle in South Korea, annual $\mathrm{CH}_{4}$ emissions increased by about $91.6 \%$ between 2005 and 2012 then decreased by about $5.8 \%$ in 2014 . Compared to the emissions in 2005, all 16 local administrative provinces showed higher $\mathrm{CH}_{4}$ emissions from the enteric fermentation of Hanwoo cattle in 2014. Among the 16 local administrativeprovinces in 2014, Gyeongsangbuk recorded as a province with highest $\mathrm{CH}_{4}$ emissions from Hanwoo cattle enteric fermentation approximately by $0.91 \mathrm{Mt} \mathrm{CO}_{2}$-eq. For the enteric fermentation of Hanwoo cattle between 2005 and 2014, local administrative provinces with an increase in the rate of $\mathrm{CH}_{4}$ emissions above $100 \%$ were Incheon $\left(+22,560.75 \mathrm{Mt} \mathrm{CO}_{2}\right.$-eq, $\left.+258 \%\right)$, Gyeonggi (+190.125 Mt $\mathrm{CO}_{2}$-eq, $\left.+119 \%\right)$, and Jeollabuk $(+272,742.75 \mathrm{Mt}$ $\mathrm{CO}_{2}$-eq, $\left.+117 \%\right)$. Lee \& Lee (2003) reported that methane emission from the enteric fermentation of Hanwoo cattle was $1.54 \mathrm{Mt}$ in 2001, whereas we found that methane emissions were 4.21 $\mathrm{Mt} \mathrm{CO}_{2}$-eq in 2014 from the enteric fermentation of Hanwoo. The largest contribution of methane from enteric fermentation was from Hanwoo cattle because of the highest population growth rate during ten-year period. Johnson \& Johnson (1995) reported that many factors influence methane emissions from cattle, including the level of feed intake, type of carbohydrate in the diet, feed processing, addition of lipids or ionophores to the diet, and alterations in the ruminal microflora. Furthermore, the results of this study (4.21 $\mathrm{Mt} \mathrm{CO}_{2}$-eq from 2,724,879 head of Hanwoo cattle in a year) were consistent with those reported by Basarab et al. (2005), who reported that $8.34 \mathrm{Mt} \mathrm{CO}_{2}$-eq were emitted from the enteric fermentation of $6,474,350$ head of Non-Korean native cattle in a year (using a Tier-2 method).

\section{$\mathrm{CH}_{4}$ emission from manure management}

Emissions of nitrous oxide from the management of Non-Korean native cattle manure were direct and indirect. Because the available data were limited for each variable, this assessment used Tier-1 method to estimate nitrous oxide emission. Annual average $\mathrm{N}$ excretion per head per year (Nex) value were used to estimate direct $\mathrm{N}_{2} \mathrm{O}$ emission. The fraction of total annual nitrogen excretion for livestock and the emission factor value that were used in this assessment were 1 and $0.006 \mathrm{~N}_{2} \mathrm{O}-\mathrm{N} / \mathrm{kg} \mathrm{N}$, respectively. These values were from the default values of the IPCC (2006). Methane emission factor is provided in Table 5 for the estimation of emission from the manure management of NonKorean native cattle in South Korea. To evaluate the contribution of cattle production sector in South Korea to global warming, the global warming potentials of the

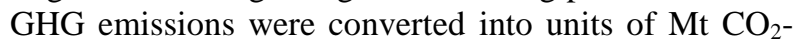
eq.

$\mathrm{CH}_{4}$ emission from manure management of cattle in South Korea between 2005 and 2014 are presented in Table 6. $\mathrm{CH}_{4}$ emissio from manure management of dairy cattle decreased by about $9.46 \%$ in between 2005 to 2014. However, the lowest emission occurred in 2011 (0.0822 Mt $\mathrm{CO}_{2}$-eq), with a slight increase 
Table 5. Emission factors to estimate methane emissions from manure management of Non-Korean native cattle in South Korea

\begin{tabular}{lccc}
\hline \hline Cattle & \multicolumn{3}{c}{ Emission factor $(\mathrm{kg} \mathrm{CH} / \mathrm{head} /$ year $)$} \\
\hline Hanwoo & under 1 year & $1 \sim 2$ years & Over 2 years \\
Male & 0.60 & 1.01 & 0.94 \\
Female & 0.57 & 0.90 & 0.91 \\
Beef & under 1 year & $1 \sim 2$ years & Over 2 years \\
Male & 0.86 & 0.97 & 1.22 \\
Female & 1.10 & 1.32 & 1.62 \\
Dairy & under 1 year & $1 \sim 2$ years & Over 2 years \\
& 0.99 & 1.16 & 2.53 \\
\hline
\end{tabular}

thereafter. Gyeonggi was the local administrative province with the highest $\mathrm{CH}_{4}$ emissions $\left(8.176 \mathrm{kt} \mathrm{CO}_{2-}\right.$ eq) from manure management in 2014. About 15 local administrative provinces showed a slight decrease in $\mathrm{CH}_{4}$ emissions from dairy cattle manure management with an annual growth rate of $-1.02 \%$, and one local administrative province (Chungcheongnam) showed an increase from $3.76 \mathrm{kt} \mathrm{CO}_{2}$-eq in 2005 to $4.05 \mathrm{kt} \mathrm{CO}_{2}$-eq in 2014.

Similarly, $\mathrm{CH}_{4}$ emission from manure management of Non-Korean native cattle in South Korea between 2005 and 2014 decreased approximately $49 \%$ with an annual growth rate of $-7.16 \%$ (Table 6 ). All the 16 local administrative provinces showed a decrease in $\mathrm{CH}_{4}$ emission from Non-Korean native cattle manure management between 2005 and 2014. Gyeonggi was the local administrative province with the highest emissions of approximately $0.872 \mathrm{kt} \mathrm{CO} 2$-eq fromcattle manure management in 2014 among the 16 local administrative provinces.

$\mathrm{CH}_{4}$ emission from manure management of Hanwoo cattle in South Korea increased between 2005 and 2014 by about $0.0252 \mathrm{MtCO}_{2}$-eq or $78 \%$. Compared to the other local administrative districts, Gyeongsangbuk showed the highest $\mathrm{CH}_{4}$ emissions from the manure management of Hanwoo cattle between 2005 and 2014 (12.32 kt $\mathrm{CO}_{2}$-eq). The local administrative provinces with increased emissions of $\mathrm{CH}_{4}$ above $100 \%$ from the manure management of Hanwoo cattle between 2005 and 2014 were Incheon (+39 kt $\mathrm{CO}_{2}$-eq, $\left.+283.89 \%\right)$, Gyeonggi (+322.51 kt $\mathrm{CO}_{2}$-eq $\left.+127.74 \%\right)$, Jeollabuk $\left(+458.99 \mathrm{ktCO}_{2}\right.$-eq, $\left.+122.92 \%\right)$, and Jeju $(+39.80$ $\mathrm{ktCO}_{2}$-eq, $+122.92 \%$ ). Annual growth rate for $\mathrm{CH}_{4}$ emission was $8.33 \%$ from manure management of Hanwoo cattle in South Korea between 2005 and 2014. Among the three types of cattle production in South Korea, methane emission increased only from the manure management of Hanwoo cattle.

\section{$\mathrm{N}_{2} \mathrm{O}$ emission from manure management}

$\mathrm{N}_{2} \mathrm{O}$ emissions from manure management of cattle are shown in Table 7. Emission of $\mathrm{N}_{2} \mathrm{O}$ during manure

Table 6. $\mathrm{CH}_{4}$ emission from the manure management of cattle in South Korea (2005-2014)

\begin{tabular}{lcccc}
\hline \hline Year & $\begin{array}{c}\text { Korean native (Hanwoo) cattle } \\
\left(\mathrm{Mt} \mathrm{CO}_{2} \text {-eq/year }\right)\end{array}$ & $\begin{array}{c}\text { Non Korean native cattle } \\
\left(\mathrm{Mt} \mathrm{CO}_{2} \text {-eq/year }\right)\end{array}$ & $\begin{array}{c}\text { Dairy cattle } \\
\left(\mathrm{Mt} \mathrm{CO}_{2} \text {-eq/year }\right)\end{array}$ & $\begin{array}{c}\text { Total } \\
(\mathrm{Mt} \mathrm{CO2-eq/year})\end{array}$ \\
\hline 2005 & 0.0320 & 0.0044 & 0.0243 & 0.0607 \\
2006 & 0.0361 & 0.0044 & 0.0234 & 0.0639 \\
2007 & 0.0405 & 0.0042 & 0.0226 & 0.0673 \\
2008 & 0.0457 & 0.0040 & 0.0220 & 0.0718 \\
2009 & 0.0501 & 0.0037 & 0.0218 & 0.0757 \\
2010 & 0.0559 & 0.0038 & 0.0215 & 0.0813 \\
2011 & 0.0587 & 0.0035 & 0.0201 & 0.0822 \\
2012 & 0.0609 & 0.0030 & 0.0211 & 0.0851 \\
2013 & 0.0605 & 0.0027 & 0.0216 & 0.0848 \\
2014 & 0.0572 & 0.0022 & 0.0220 & 0.0815 \\
\hline
\end{tabular}


Table 7. $\mathrm{N}_{2} \mathrm{O}$ emissions from the manure management of cattle in South Korea (2005-2014)

\begin{tabular}{lcccc}
\hline \hline Year & $\begin{array}{c}\text { Korean native (Hanwoo) cattle } \\
(\text { Mt CO2-eq/year) }\end{array}$ & $\begin{array}{c}\text { Non Korean native cattle } \\
\left(\mathrm{Mt} \mathrm{CO}_{2} \text {-eq/year) }\right.\end{array}$ & $\begin{array}{c}\text { Dairy cattle } \\
(\text { Mt CO2-eq/year })\end{array}$ & $\begin{array}{c}\text { Total } \\
(\text { Mt CO2-eq/year) }\end{array}$ \\
\hline 2005 & 0.3112 & 0.0541 & 0.1440 & 0.5093 \\
2006 & 0.3503 & 0.0530 & 0.1391 & 0.5424 \\
2007 & 0.3914 & 0.0508 & 0.1347 & 0.5769 \\
2008 & 0.4390 & 0.0493 & 0.1318 & 0.6200 \\
2009 & 0.4784 & 0.0462 & 0.1306 & 0.6552 \\
2010 & 0.5328 & 0.0469 & 0.1284 & 0.7081 \\
2011 & 0.5585 & 0.0424 & 0.1186 & 0.7195 \\
2012 & 0.5777 & 0.0372 & 0.1219 & 0.7369 \\
2013 & 0.5673 & 0.0338 & 0.1243 & 0.7254 \\
2014 & 0.5359 & 0.0275 & 0.1263 & 0.6897 \\
\hline
\end{tabular}

treatment occurs in two forms, direct and indirect. Total $\mathrm{N}_{2} \mathrm{O}$ emission from manure management of dairy cattle between 2005 and 2014 decreased by about 14\%. The lowest $\mathrm{N}_{2} \mathrm{O}$ emission from dairy cattle manure management occurred in 2011, which increased thereafter. The largest decrease in percent emission was in Daejeon $(-100 \%)$, followed by Daegu $(-13.93 \%)$, whereas Chungcheongnam was the local administrative district with the largest increase in $\mathrm{N}_{2} \mathrm{O}$ emission from manure management of dairy cattle by approximately $114.9 \%$ in 2014 compared to that in 2005 . Total $\mathrm{N}_{2} \mathrm{O}$ emission from manure management of Non-Korean native cattle between 2005 and 2014 decreased by approximately $49.10 \%$. Local administrative district with the highest emission in 2014 was Gyeonggi $\left(11,033 \mathrm{kt} \mathrm{CO}_{2}\right.$-eq), whereas the lowest emissions was in Daejeon (0 kt $\mathrm{CO}_{2}$-eq). Those all local administrative districts showed a decrease in $\mathrm{N}_{2} \mathrm{O}$ emission from nonKorean native cattle manure management. Daejeon showed the largest decrease of about $100 \%$ and Seoul with the smallest decrease of about $6.36 \%$. Local administrative provinces that had decreases in emission above $30 \%$ during last ten years were Incheon, Gwangju, Daejeon, Ulsan, Gyeonggi, Gangwon, Chungcheongbuk, Chungcheongnam, Jeollabuk, Jeollanam, Gyeongsangbuk, Gyeongsangnam, and Jeju, with decreases rate of approximately 83.79, 92.27, $100,00,79.99,32.02,46.18,57.52,37.63,67.67,44.19$, 51.14, 78.20, and 78.56\%, respectively. Local administrative provinces with decrease rate below $30 \%$ were Seoul (6.36\%), Busan (6.86\%) and Daegu $(25.39 \%)$.

In contrast, total $\mathrm{N}_{2} \mathrm{O}$ emission from manure management of Hanwoo cattle increased. Compared to emission in 2005, $\mathrm{N}_{2} \mathrm{O}$ emissions from Hanwoo cattle manure management in 2014 increased by approximately $72.2 \%$, although the emission decreased from 2012 by approximately (7.2\%). Those 16 local administrative provinces had increased emission from manure management of Hanwoo cattle. Local administrative province with the highest $\mathrm{N}_{2} \mathrm{O}$ emission in 2014 was Gyeongsangbuk (0.11 $\mathrm{Mt} \mathrm{CO}_{2}$-eq).

\section{$\mathrm{CO}_{2}$ emissions from direct on-farm energy use for cattle production}

Direct on-farm energy use in cattle production is the use of energy for the milking, ventilation, heating and lighting, heating of water, and watering and feeding of animals. Three years of $\mathrm{CO} 2$ emissions from the direct on-farm energy used for cattle production in South Korea between 2005 and 2014 are shown in Table 8 . The CO2 emissions from direct on-farm energy use for dairy cattle in South Korea decreased from 62,050.02 t $\mathrm{CO} 2$ in 2005 to $51,272.13 \mathrm{t} \mathrm{CO} 2$ in 2011 , with an increase to $55,471.87$ t CO2 in 2014. The local province of Chungcheongnam was the only province to show an increase in $\mathrm{CO} 2$ emissions from direct on-farm energy used in dairy cattle production of approximately 568.31 t $\mathrm{CO} 2$ for the ten-year period. In the other 15 local administrative provinces, the $\mathrm{CO} 2$ emissions from direct on-farm energy use for dairy cattle production in South Korea decreased. The highest emissions of $\mathrm{CO} 2$ for dairy cattle production were in Gyeonggi $(21,580.82$ $\mathrm{t} \mathrm{CO} 2$ ) in 2014; however, these emissions were decreased compared to those in 2005 by approximately 23,969.34 $\mathrm{t} \mathrm{CO} 2$. The decrease in percent $\mathrm{CO} 2$ emissions from the direct on-farm energy use in dairy cattle production between 2005 and 2014 ranged from $6.01 \%$ (Busan) to $100 \%$ (Daejeon), with an average decrease of approximately $23.20 \%$. 
Table 8. $\mathrm{CO}_{2}$ emissions from the direct on-farm energy use for cattle production in South Korea (2005-2014)

\begin{tabular}{lcccc}
\hline \hline Year & $\begin{array}{c}\text { Korean native (Hanwoo) } \\
\text { cattle (Mt CO2-eq/year) }\end{array}$ & $\begin{array}{c}\text { Non-Korean native cattle } \\
\text { (Mt CO } \text {-eq/year) }\end{array}$ & $\begin{array}{c}\text { Dairy cattle } \\
\text { (Mt CO } \text {-eq/year) }\end{array}$ & $\begin{array}{c}\text { Total } \\
\text { (Mt CO2-eq/year) }\end{array}$ \\
\hline 2005 & 0.1490 & 0.0172 & 0.0621 & 0.2283 \\
2006 & 0.1690 & 0.0172 & 0.0598 & 0.2461 \\
2007 & 0.1901 & 0.0165 & 0.0579 & 0.2646 \\
2008 & 0.2166 & 0.0159 & 0.0566 & 0.2891 \\
2009 & 0.2377 & 0.0149 & 0.0561 & 0.3087 \\
2010 & 0.2677 & 0.0154 & 0.0553 & 0.3383 \\
2011 & 0.2822 & 0.0144 & 0.0513 & 0.3479 \\
2012 & 0.2912 & 0.0124 & 0.0533 & 0.3570 \\
2013 & 0.2900 & 0.0116 & 0.0546 & 0.3561 \\
2014 & 0.2771 & 0.0095 & 0.0555 & 0.3421 \\
\hline
\end{tabular}

The emissions from direct on-farm energy use of NonKorean native cattle production in South Korea decreased by about $0.44 \%$ during last ten years. All the 16 local administrative provinces showed decreases in the emissions from direct on-farm energy use for NonKorean native cattle production. The local administrative district showed the highest emissions from direct on-farm energy use in Non-Korean native cattle production in 2014 was Gyeonggi $(3,559.52 \mathrm{kt}$ $\mathrm{CO}_{2}$-eq), and the lowest emissions was in Daejeon (0 $\mathrm{t}$ $\mathrm{CO}_{2}$-eq) since Non-Korean native cattle population has not been growth in Daejeon on 2012. $\mathrm{CO}_{2}$ emission decreased by more than $50 \%$ during the last ten-year period in 7 local administrative provinces, which were Incheon (-81.94\%), Gwangju (-91.87\%), Daejeon ($100 \%)$, Ulsan $(-80.52 \%)$, Chungcheongbuk $(-51.96 \%)$ Jeollabuk (-63.28\%), Gyeongsangnam $(-75.11 \%)$, and Jeju $(-79.89 \%)$. The decreases in $\mathrm{CO}_{2}$ emission were less than $50 \%$ in 8 local administrative provinces, which were Seoul $(-15.16 \%)$, Busan $(-23.80 \%)$, Daegu $(-10.94 \%)$, Gyeonggi (-25.55\%), Gangwon (-47.45\%), Chungcheongnam $(-28.85 \%)$, Jeollanam $(-43.11 \%)$, and Gyeongsangbuk (-44.75\%). Decrease in $\mathrm{CO}_{2}$ emission from direct on-farm energy use in Non-Korean native cattle production was likely because of the decrease in the population of Non-Korean native cattle in those areas. Average decrease in $\mathrm{CO}_{2}$ emission from direct on-farm energy use in Non-Korean native cattle production between 2005 and 2014 in South Korea was approximately $54.01 \%$.

In contrast to that of Non-Korean native cattle production, $\mathrm{CO}_{2}$ emission from the on-farm energy use in Hanwoo cattle production increased from 2005 to 2012, then thereafter start to decrease. $\mathrm{CO}_{2}$ emission from direct on-farm energy use in the production of Hanwoo cattle in 2014 increased by approximately $85 \%$ compared to that in 2005. Local administrative district with the highest $\mathrm{CO}_{2}$ emission from direct on-farm energy use in the production of Hanwoo cattle in 2014 was Gyeongsangbuk $\left(59,820.40 \mathrm{kt} \mathrm{CO}_{2}\right.$-eq). Seoul was the district with the lowest $\mathrm{CO}_{2}$ emission of approximately $8.23 \quad \mathrm{kt} \quad \mathrm{CO}_{2}$-eq. Four local administrative provinces that increase in $\mathrm{CO}_{2}$ emission from direct on-farm energy use in Hanwoo cattle production above $100 \%$ during the last ten years were Incheon (283.89\%), Gyeonggi (127.74\%), Jeollabuk $(122.92 \%)$ and Jeju (102.78\%). Development of Hanwoo cattle industry has been focused in these areas during last ten years, and therefore, the energy used for operating farm facilities increased as the increase of Hanwoo cattle population.

\section{Global warming potential of GHG emission from cattle production}

Global warming potential of the GHG emission from cattle production in South Korea between 2005 and 2014 is shown in Figure 1. Total global warming potential of the GHG emission from cattle production in South Korea was approximately 60.7 Mt CO2-eq between 2005 and 2014. The GWPs of emission increased from 4.67 Mt CO2-eq in 2005 to the highest emission in 2012 of about $6.97 \mathrm{kt} \mathrm{CO} 2$-eq, which then decreased to $6.65 \mathrm{Mt} \mathrm{CO}$-eq in 2014. The largest contribution to emission from cattle production was methane from enteric fermentation, which was approximately 50.72 Mt CO2-eq and comprised $83.52 \%$ of the total emission. The contribution from $\mathrm{N}_{2} \mathrm{O}$ from manure management was less $(6.173 \mathrm{Mt} \mathrm{CO} 2-\mathrm{eq}$, $10.16 \%$ of total emissions), from $\mathrm{CO}_{2}$ from direct onfarm energy use was $3.078 \mathrm{Mt} \mathrm{CO}$-eq $(5.1 \%$ of total 
emissions) and methane from manure management was $0.754 \mathrm{Mt} \mathrm{CO}_{2}$-eq $(1.2 \%$ of total emissions).

During the ten-year period (2005-2014), total emission from enteric fermentation from production of cattle in South Korea increased by approximately $42 \%$. For comparison, GIR (2013) reported that total emission from enteric fermentation in a 10 -year period in South Korea increased by approximately $9.7 \%$. The estimatic increase in emission from enteric fermentation of cattle in the ten years of this study might represent the increase in the contribution of cattle production to total methane emission. The differences between the two estimates were primarily because the IPCC Tier-2 model significantly overpredicts cattle GE intake at higher level intake. This over predict was also reported by Jo et al. (2015) with Hanwoo steers study.
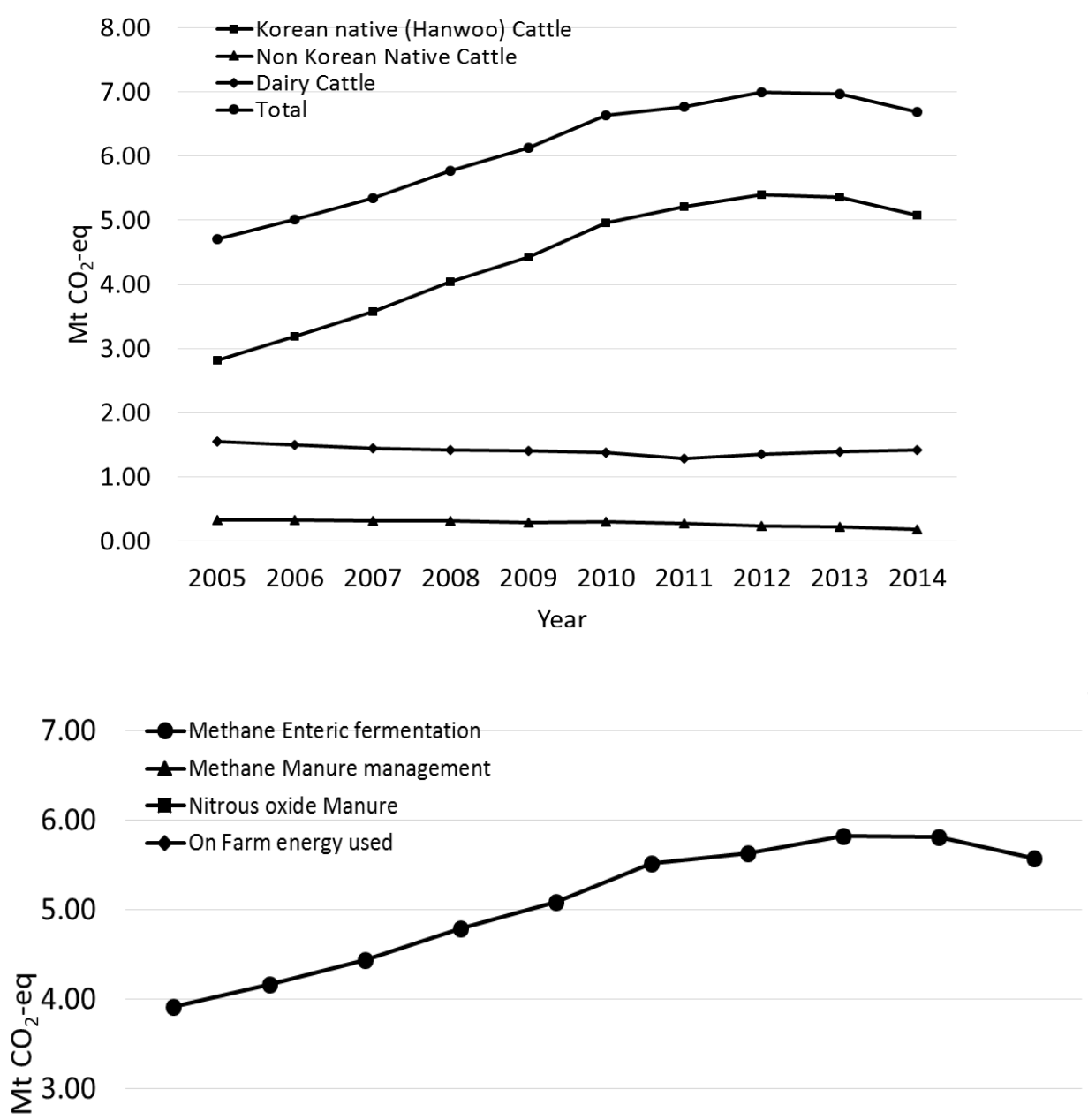

2.00

1.00

0.00

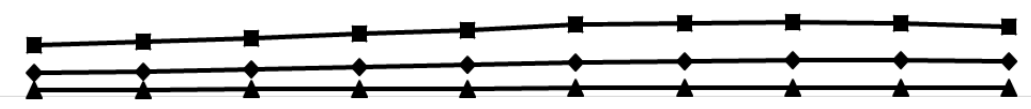

$\begin{array}{llllllllll}2005 & 2006 & 2007 & 2008 & 2009 & 2010 & 2011 & 2012 & 2013 & 2014\end{array}$

Figure 1. Global warming potential of GHG emission by cattle type (A) and by emission type (B) from cattle livestock production activities in South Korea in between 2005-2014. 
Furthermore, it is consensused that the enteric fermentation of cattle is the largest source of $\mathrm{CH}_{4}$ emission in the livestock sector (FAO 2006).

The highest emission of greenhouse gases during the ten-year period (2005-2014) of approximately 44.081 Mt CO2-eq was generated in the production of Hanwoo cattle, which was followed by dairy cattle production (13.84 Mt CO2-eq) and Non-Korean native production (2.80 kt CO2-eq). Compared with the level in 2005, the greenhouse gas emission from production of Hanwoo cattle have not reached the declared target level of a $30 \%$ reduction by 2020 (4\% lower than the 2005 level) with 5.08 Mt CO2-eq produced in 2014, which was $80 \%$ higher than that in 2005 (2.82 Mt CO2eq). However, target levels for the reduction in greenhouse gas emission from the production of both Non-Korean native beef and dairy cattle were reached. Emissions from production of Non-Korean native cattle were $0.18 \mathrm{Mt} \mathrm{CO} 2$-eq in 2014, which was $45 \%$ lower than that in 2005 (0.33 Mt CO2-eq).

Annual average and annual growth rate of $\mathrm{GHG}$ emission from cattle production in South Korea between 2005 and 2014 are shown in Figure 2. Annual average GHG emission from Hanwoo cattle production was 4,408.13 kt CO2-eq/y, which was higher than that Non-Korean native cattle production (280.46 kt CO2eq/y) and dairy cattle production $(1,384.17 \mathrm{kt}$ CO2from production of Hanwoo cattle was $6.06 \%$ between 2005 and 2014. By contrast, average annual growth rate of GHG emission from beef and dairy cattle production was $-5.83 \%$ and $-0.92 \%$, respectively (eq/y). Average annual growth rate of GHG emission

Annual average GHG emission from the production of Hanwoo beef and dairy cattle by province in South

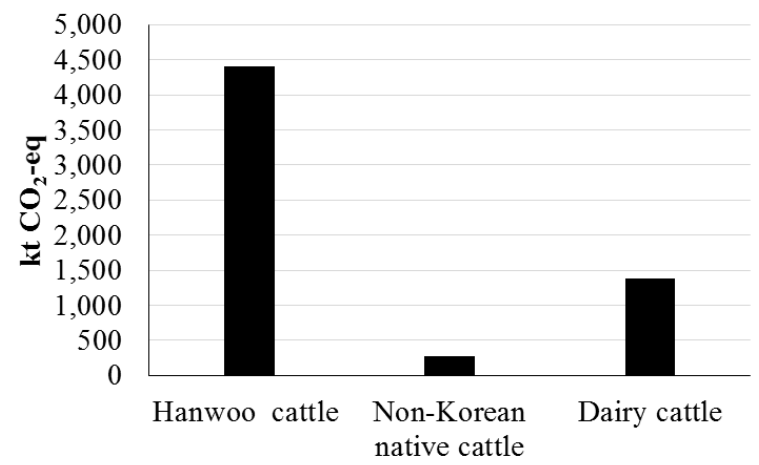

Korea between 2005 and 2014 are shown in Figure 3. Local administrative district with the highest annual average GHG emission from the production of Hanwoo cattle was Gyeongsangbuk (874,088.35 t CO2-eq/y), whereas Seoul had the lowest emissions (309.28 t CO2eq/y). In 8 local administrative provinces, annual average GHG emission from the production of Hanwoo cattle was above 200,000 t CO2-eq/y, which included Gyeonggi (329,236.88 t CO2-eq/y), Gangwon (333,708.28 t CO2-eq/y), Chungcheongbuk (276,040.47 t CO2-eq/y), Chungcheongnam $(545,616.62$ t CO2eq/y), Jeollabuk (483,579.63 t CO2-eq/y), Jeollanam (717,474.71 t CO2-eq/y), Gyeongsangbuk (874,088.35 t $\mathrm{CO} 2-\mathrm{eq} / \mathrm{y})$, and Gyeongsangnam $(459,675.92$ t CO2$\mathrm{eq} / \mathrm{y})$. The highest annual growth rate in GHG emissions from the production of Hanwoo cattle was in Incheon (12.73\% per year), and the lowest annual growth rate was in Seoul (1.99\% per year). In contrast to the emission from production of Hanwoo cattle, the highest annual average of GHG emission from beef and dairy cattle production was in Gyeonggi Province, with $102,811.80$ and $579,239.60$ t $\mathrm{CO}_{2}$-eq/y, respectively. Daejeon was the local administrative province with the lowest annual growth rates for the emissions from beef and dairy cattle production, with approximately $-27.72 \%$ and $-47.81 \%$ per year, respectively. From this study, the local towns primarily produced the GHG emission from the production of Hanwoo cattle compared with the metropolitan areas. The annual growth rate of GHG emissions from production of Hanwoo cattle was considerably higher than that of beef and dairy cattle production.

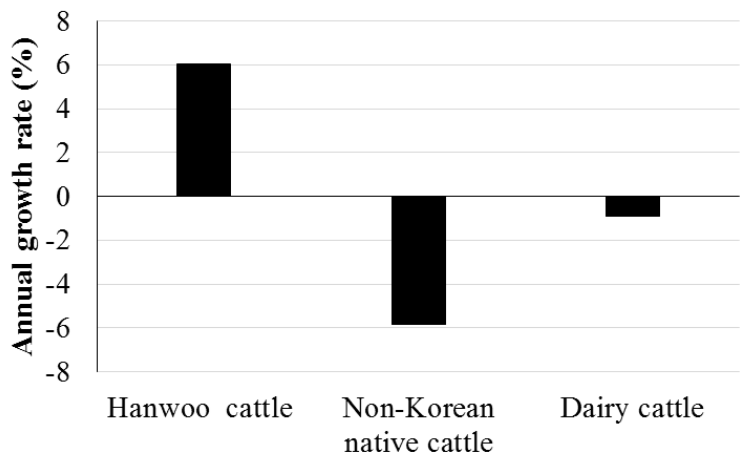

Figure 2. Annual average (A) and annual growth rate (B) of GHG emission from cattle production in South Korea (2005-2014). 

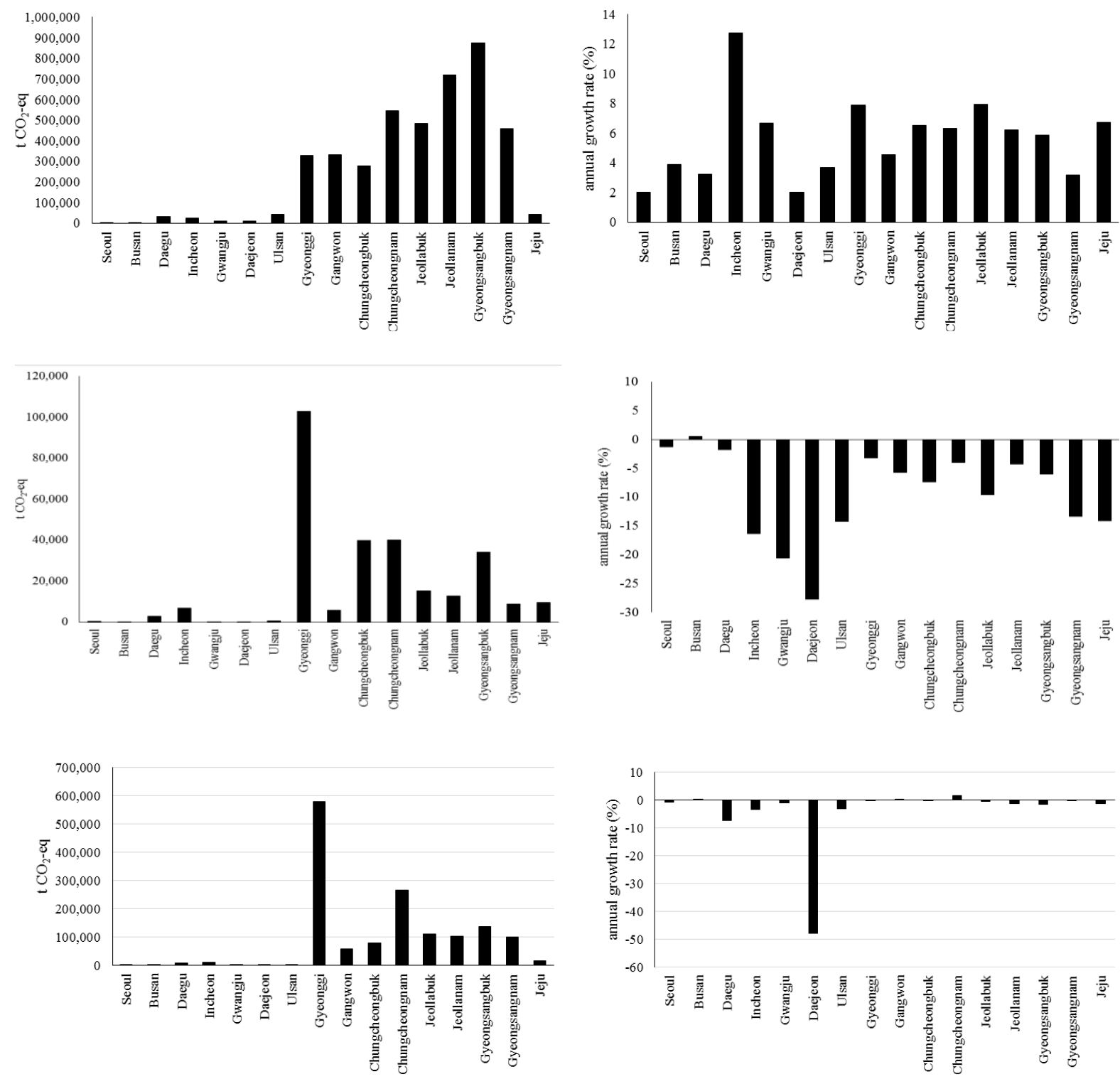

Figure 3. Annual average and annual growth rate of GHG emission from the production of Hanwoo cattle (A), Non-Korean native cattle (B) and Dairy cattle (C) by province in South Korea (2005-2014).

Results of correlation analyses between the cattle type and GHG emission in South Korea from 2005 to 2014 are provided in Table 9. Correlation coefficient of $\mathrm{CH}_{4}$ emission from the enteric fermentation of Hanwoo cattle and the total $\mathrm{CH}_{4}$ emission was 0.999, which was higher than that Non-Korean native cattle $(-0.823)$ or dairy cattle $(-0.947)$. Correlation coefficient of $\mathrm{CH}_{4}$ emission from the manure management of Hanwoo cattle and total $\mathrm{CH}_{4}$ emission was 0.998 , which was higher than that Non-Korean native cattle $(-0.817)$ or dairy cattle (-0.944). Correlation coefficient of $\mathrm{NO}_{2}$ emission from manure management of Hanwoo cattle and total $\mathrm{NO}_{2}$ emission was 0.956 , which was higher than that Non-Korean native cattle $(-0.715)$ or dairy cattle (-0.934). Correlation coefficient of $\mathrm{CO}_{2}$ emission from on-farm energy use in production of Hanwoo cattle and total $\mathrm{CO}_{2}$ emission was 0.999 , which was higher than that Non-Korean native cattle (-0.819) or dairy cattle (-0.951). Correlation coefficient was 0.999 between the global warming potential of GHG emission from production of Hanwoo cattle and total global warming potential of GHG emission, which was higher than that Non-Korean native cattle $(-0.818)$ or dairy cattle (-0.949). Those showed that production of Hanwoo cattle was the primary contributor to total $\mathrm{CH} 4$ emission from enteric fermentation, $\mathrm{CH} 4$ emission from 
Table 9. Correlation analysis between cattle type and GHG emission in South Korea from 2005 to 2014

\begin{tabular}{lccccc}
\hline \hline & $\begin{array}{c}\text { CH4 enteric } \\
\text { fermentation }\end{array}$ & $\begin{array}{c}\text { CH4 manure } \\
\text { management }\end{array}$ & $\begin{array}{c}\text { NO2 manure } \\
\text { management }\end{array}$ & $\begin{array}{c}\text { CO2 on farm } \\
\text { energy use }\end{array}$ & $\begin{array}{c}\text { Global warming } \\
\text { potential }\end{array}$ \\
\hline Hanwoo & 0.999 & 0.998 & 0.956 & 0.999 & 0.999 \\
$\begin{array}{l}\text { Non-Korean native } \\
\text { cattle }\end{array}$ & -0.823 & -0.817 & -0.715 & -0.819 & -0.818 \\
Dairy & -0.947 & -0.944 & -0.934 & -0.951 & -0.949 \\
\hline
\end{tabular}

manure management, NO2 emission from manure management, $\mathrm{CO} 2$ emission from on-farm energy use, and total global warming potential of GHG emission from cattle production sector in South Korea.

However, both overestimates and underestimates of emissions were possible in this study. Kebreab et al. (2008) reported that the IPCC values result in an overestimate of emissions by approximately $12.5 \%$ and an underestimate by approximately $9.8 \%$ for dairy and feedlot cattle, respectively. In this study, about $31.18 \%$ overestimates of enteric fermentation occurred which was higher than the one reported by GIR (2013).

\section{CONCLUSION}

Emissions of greenhouse gases from the cattle production sector in South Korea increased year to year and failed to reach the target pledge of a $30 \%$ reduction compared with current levels. Production of Hanwoo cattle was the primary contributor to $\mathrm{CH}_{4}$ emission from enteric fermentation, $\mathrm{CH}_{4}$ emission from manure management, $\mathrm{NO}_{2}$ emission from manure management and $\mathrm{CO}_{2}$ emissions from on farm energy use in the cattle production sector of South Korea during the tenyear period of this study. Proper mitigation is required in the cattle production sector to meet the target pledge for emission in 2020. Mitigation options for reductionsin emission should focus on the production of Hanwoo cattle because of the significant contributions to greenhouse gas emission in South Korea.

\section{ACKNOWLEDGEMENTS}

This work was supported by the Animal Environmental and Bioengineering Laboratory, Department of Agricultural Biotechnology, Seoul National University (SNU), Seoul, South Korea. The authors would like to thank the Korean Institute of Planning \& Evaluation for Technology in Food, Agriculture, Forestry \& Fisheries (IPET) and the Korean Energy Technology Evaluation and Planning (KETEP) for financial support during this study.

\section{REFERENCES}

[AAFCCT] Agriculture and Agri-Food Climate Change Table. 2000. Options report: Reducing greenhouse gas emissions from Canadian Agriculture. Publication No. 2028/E.

Amon B, Kryvoruchko V, Amon T, Zechmeister-Boltenstern S. 2006. Methane, nitrous oxide and ammonia emissions during storage and after application of dairy cattle slurry and influence of slurry treatment. Agric Ecosyst Environ. 112:153-162. doi: 10.1016/j.agee.2005.08.030.

Basarab JA, Okine EK, Baron VS, Marx T, Ramsey P, Ziegler K, Lyle K. 2005. Methane emissions from enteric fermentation in Alberta's Non-Korean native cattle population. Can J Anim Sci. 501:2-13. doi: 10.4141/A04-069.

[FAO] Food and Agriculture Organization. 2006. Livestock's long shadow: Environmental issues and options. Rome (Italy): Food and Agriculture Organization of the United Nations.

Gerber PJ, Steinfeld H, Henderson B, Mottet A, Opio C, Dijkman J, Falcucci A, Tempio G. 2013. Tackling climate change through livestock: a global assessment of emissions and mitigation opportunities. Rome (Italy): Food and Agriculture Organization, United Nations.

[GIR] Gas Inventory and Research. 2013. National greenhouse gas inventory report of Korea. Seoul (Korea): Greenhouse Gas Inventory and Research Center of Korea.

Höglund-Isaksson L. 2012. Global anthropogenic methane emissions 2005-2030: Technical mitigation potentials and costs. Atmosph Chemist Phys. 12:9079-9096. doi: 10.5194/acp-12-9079-2012.

[IPCC] Intergovernmental Panel on Climate Change. 2006 IPCC Guidelines for National Greenhouse Gas Inventories, Prepared by the National Greenhouse Gas Inventories Programme. Eggleston HS, Buendia L, Miwa K, Ngara T, Tanabe K, editors. Kanalawa (Jpn): Institute for Global Environmental Strategies.

Ji ES, Park KH. 2012. Methane and nitrous oxide emissions from livestock agriculture in 16 local administrative provinces of Korea. Asian-Aust J Anim Sci. 25:17681774. doi: 10.5713/ajas.2012.12418. 
Jo N, Kim J, Seo S. 2015. Estimation of methane emission factor for enteric fermentation of growing-finishing Hanwoo steers using the IPCC Tier 2 approach. Peer J Pre Prints 3:e1578. doi: 10.7287/peerj.preprints. $1285 \mathrm{v} 1$.

Johnson KA, Johnson DE. 1995. Methane emissions from cattle. J Anim Sci. 73:2483-2492. doi: 10.2527/1995. $7382483 x$.

Kebreab E, Johnson KA, Archibeque SL, Pape D, Wirth T. 2008. Model for estimating enteric methane emissions from United States dairy and feedlot cattle. J Anim Sci. 86:2738-2748. doi: 10.2527/jas.2008-0960.

Lee HJ, Lee SC. 2003. National methane inventory relevant to livestock enteric fermentation. Korean J Anim Sci Technol. 45:997-1006. doi: 10.5187/JAST.2003. 45.6.997.

Merino P, Ramirez-Fanlo E, Arriaga H, del Hierro O, Artetxe A, Viguria M. 2011. Regional inventory of methane and nitrous oxide emission from ruminant livestock in the Basque country. Anim Feed Sci Technol. 166-167:628640.

Opio C, Gerber P, Mottet A, Falcucci A, Tempio G, MacLeod M, Vellinga T, Henderson B, Steinfeld H. 2013.
Greenhouse gas emissions from ruminant supply chainsA global life cycle assessment. Rome (Italy): Food and Agriculture Organization, United Nations.

Patra AK. 2014. Trends and projected estimates of GHG emissions from Indian livestock in comparisons with GHG emissions from world and developing countries. Asian Australas J Anim Sci. 27:592-599. doi: 10.5713/ajas.2013.13342.

Smith P, Martino D, Cai Z, Gwary D, Janzen H, Kumar P, McCarl B, Ogle S, O’Mara F, Rice C, Scholes B, Sirotenko O. 2007. Agriculture. In: Metz, B, Davidson OR, Bosch PR, Dave R, Meyer LA, editors. Climate change 2007: Mitigation. Contribution of Working Group III to the Fourth Assessment Report of the Intergovernmental Panel on Climate Change. Cambridge (UK): Cambridge University Press.

[UNFCCC] United Nations Framework Convention on Climate Change. 2011. FCCC/AWGLCA/2011/INF.1. United Nations.

[USEPA] United States of Environmental Protection Agency. 2014. Climate change indicators in the United States, 2014. 3th ed. EPA 430-R-14-004. www.epa.gov/ climatechange/indicators. 